\title{
PERÍMETROS DE PROTEÇÃO PARA FONTES NATURAIS DE ÁGUAS MINERAIS
}

\author{
Virginia M. T. Coelho ${ }^{1}$ \\ Uriel Duarte
}

\begin{abstract}
RESUMO
O presente trabalho aborda a questão dos perímetros de proteção que devem ser definidos e instalados ao redor das captações ligadas à produção de águas minerais, quer sejam fontes naturais ou poços profundos, de acordo com a legislação atual. Aqui é descrita e aplicada uma metodologia para definição destes perímetros, baseada na condutividade hidráulica do meio poroso e no decaimento bacteriológico, em função do tempo de trânsito do contaminante neste meio. De acordo com esta metodologia, proposta para fontes naturais de água mineral, são calculados e delineados três perímetros, ou seja: Zona Imediata (distância obrigatória que independe da geologia, fixada em 10 metros), Zona Próxima (preferencialmente para proteção de contaminação bacteriológica) e Zona Afastada (limite da área de recarga). Esta metodologia, baseada em dados reais do meio poroso, mostrou ser de fácil aplicação e compreensão nos três contextos geológicos pesquisados, tendo sido já aceita pelos técnicos de nosso setor governamental, responsáveis pela análise dos relatórios de pesquisa mineral.
\end{abstract}

Palavras Chaves: perímetros de proteção, águas subterrâneas, condutividade hidráulica, meios porosos, decaimento bacteriológico, fontes naturais de águas minerais.

\section{ABSTRACT}

The present work covers the problem to delineate protection areas around both natural sources and wellheads that produce mineral waters, according the present legal concerns. A methodology to define such perimeters is described and applied. It is based on the hydraulic conductivity of the porous medium and bacteriological decay as function of the contaminant transit time in the medium. According the methodology here proposed for natural sources of mineral water, three perimeters are calculated and delineated: Immediate Zone (obligatory zone, independent of the geology and fixed to 10 meters); Near Zone (preferentially for bacteriological contamination protection) and Far Zone (border of the recharge area). That metodology, based on porous medium real data, showed to of easy application and understanding in the three geological situations tested. It was also accepted by the governmental agencies responsible by the evaluation of the reports for mineral exploration.

Keywords: protection perimeters, groundwaters, hydraulic conductivity, porous medium, natural sources of mineral water.

\section{INTRODUÇÃO}

Apesar da importância da água subterrânea como insumo básico para o abastecimento público e para a indústria, a hidrogeologia como ciência precisa de investimentos para aprofundar um nível de conhecimento técnico-científico que possibilite avanços na exploração, aproveitamento e proteção destes recursos hídricos. A atividade de captação e explotação de água subterrânea depende de dispositivos institucionais que disciplinem, controlem ou fiscalizem o seu exercício. A falta desses instrumentos legais coloca em risco a qualidade dos aqüíferos e estes, uma vez poluídos e/ou contaminados, sua

\footnotetext{
${ }^{1}$ Departamento de Geologia Sedimentar e Ambiental - Instituto de Geociências - USP. Rua do Lago 562, CEP 05508-900, São Paulo, SP.
} 
recuperação é de longa duração, tecnicamente difícil e muitas vezes economicamente inviável. Assim, recentemente, foram instituídas portarias e leis, ligadas à produção de águas minerais, que devido ao seu crescente consumo, não mais se restringem à captações de fontes naturais. Tais águas são produzidas em igualdade de volume por poços profundos localizados em áreas favoráveis e, levam em consideração a economia de transporte entre produtor e consumidor e qualidade físico-química-bacteriológica das águas comercializadas.

Como resultado do conjunto de medidas destinadas à preservação da qualidade dessas águas em relação aos aspectos químicos, físicos e bacteriológicos, foram instituídos por portaria do Departamento Nacional de Produção Mineral - DNPM, os denominados Perímetros de Proteção, que devem ser definidos e instalados ao redor das captações, quer sejam fontes naturais ou poços profundos.

Analisando a Portaria-DNPM $\mathrm{n}^{\circ}$ 231/98 e o exemplo prático de sua aplicação no texto sobre "Áreas de proteção das fontes de água mineral da região de Lindóia, Águas de Lindóia e Serra Negra - São Paulo" (Mente \& Cruz, 1998), notamos uma deficiência na utilização do modelo apresentado, quando relacionado a perímetros de proteção de fontes naturais.

A utilização de modelos matemáticos para definir perímetros de proteção é bastante eficiente em se tratando de poços bombeados, pelo fato de que estes apresentam o cone de rebaixamento no nível freático e seu limite determina o perímetro imediato de proteção ou, a denominada Zona de Influência prevista na legislação. Por outro lado, as fontes funcionam como um dreno, fluem naturalmente e não apresentam o cone de rebaixamento provocado pelo bombeamento. Neste caso, podemos afirmar que a zona de influência de uma fonte natural abrange toda sua zona de recarga.

Isto nos levou a idealizar uma proposta metodológica para delimitação de perímetros de proteção, exclusivas às captações de água por fontes naturais.

Diversos experimentos já foram realizados utilizando o critério de tempo de trânsito da água no subsolo como método 78 para eliminação de vírus e bactérias patogênicas, obtendo resultados melhores e mais confiáveis, por estar mais diretamente relacionado com as características hidrodinâmicas do solo, do que o critério das distâncias mínimas, que independe desse fator. Todavia, o cálculo do tempo de trânsito mínimo, em alguns casos, pode não dar uma garantia suficiente, sendo então necessário, o conhecimento das características dispersivas do meio que podem ser identificáveis em meios heterogêneos e em rochas fraturadas. O caráter saturado ou não do solo, seu potencial redox, temperatura, granulometria ou fraturamento, capacidade de absorção, existência de nutrientes, inibidores e produtores da atividade biológica, são fatores importantes que não podem ser desconsiderados.

Neste trabalho é apresentado uma metodologia de fácil aplicação para delimitação de perímetros de proteção de acordo com a Portaria DNPM - $n^{\circ} 231 / 98$ embasada nas características hidrodinâmicas da porção não saturada do solo e, principalmente, em bibliografia científica atualizada sobre as pesquisas que constataram o tempo de decaimento bacteriológico quando se introduz esse contaminante em zonas experimentais.

Assim, utilizando-se dos conceitos básicos de condutividade hidráulica e tempo de decaimento bacteriológico, podemos calcular as distâncias mínimas de proteção, com grande segurança contra os agentes contaminantes/poluentes, sabedores de que todas as fontes naturais possuem contribuição local das águas de seu entorno.

\section{POLUIÇÃO E CONTAMINAÇÃO DAS ÁGUAS SUBTERRÂNEAS}

As mudanças da qualidade das águas subterrâneas podem ser causadas direta ou indiretamente por diversas atividades do homem. Influências diretas, resultam de substâncias naturais ou artificias que são introduzidas no ciclo geoquímico pelo homem e, finalmente, alcançam as águas subterrâneas. Influências indiretas, são as mudanças de qualidade causadas sem a interferência do homem, ou seja, àquelas que ocorrem devido a processos químicos, físicos e biológicos naturais. Assim, qualquer alteração na qualidade da água subterrânea de origem antrópica no sistema aqüífero, é denominada poluição e 
quando esta alteração ou degradação da qualidade natural das águas subterrâneas atinge níveis que podem afetar, de forma prejudicial, a saúde humana e dos animais que a consomem, é denominada contaminação.

A urbanização, a industrialização, as práticas agrícolas e a extração mineral são as principais atividades humanas que geram resíduos. Estes, quando lançados no solo, rios e/ou atmosfera, transformam-se em fontes potenciais de poluição e/ou contaminação das águas subterrâneas. $\mathrm{Na}$ identificação destas fontes potenciais de poluição, é de importância fundamental classificá-las, de acordo com o grau de extensão, em pontuais (de pequena escala e facilmente identificáveis) e difusas (relativamente dispersas, atingem grandes superfícies e originam-se de outras fontes menores cujas localizações não são bem definidas).

\section{ASPECTOS COMPORTAMENTAIS POLUIÇÃO/CONTAMINAÇÃO}

Existem perfis naturais de solo que podem degradar alguns poluentes até atingirem a água subterrânea. A noção de solo depurativo levou à prática da disposição de excretos humanos e águas residuais domésticas sobre o solo.

\section{Processos}

hidrogeológicos,

hidrogeoquímicos e bioquímicos em subsolo, controlam o tipo, extensão e duração das influências da atividade antrópica nas águas subterrâneas.

Como os perfis de solo $e$ as condições hidrogeológicas diferenciam-se de uma região para outra, o caráter efetivo para atenuar os poluentes também variam.

Segundo Jimena (1986), a circulação da água pelo solo é indicada como um bom método para eliminação de vírus e bactérias patogênicas e, para que isso ocorra é necessário um tempo de trânsito mínimo de 30 a 60 dias, tendendo a aumentar esse tempo para 90 dias ou mais.

Baxter e Edworthy (1979) em solo poroso e fraturado verificaram que numa distância de 300 metros do ponto de infiltração do contaminante, ocorreu decaimento total de vírus e uma redução de até $10^{4}$ de bactérias patogênicas com presença de cloro residual.

Em solo de areia fina a redução foi superior a $10^{4}$ de bactérias patogênicas em apenas 8 metros de percolação (Edworthy e
Downing, 1979). Porém, outros perfis de solo, são menos favoráveis, citando-se sobrevivências superiores a 100 dias (Kaddu-Mulindwa et al., 1983); e coliformes percorrendo até 840 metros e vírus tipo pólio em profundidades de até 30 metros, depois de 180 metros da área de infiltração (Yaruz e Haridas, 1984).

Estudos realizados na Holanda em dunas, mostrou que são necessários dois meses para que ocorra eliminação total de vírus e bactérias no subsolo (Puffelen, 1979). Em Israel, também em dunas, a eliminação foi total aos 100 dias (Shelef, 1979).Vírus e bactérias patogênicas decaem mais rápido e em maior número em solo insaturado (Berend, 1970), (Loeffler et al., 1973), (Romero, 1970).

$\mathrm{Na}$ Califórnia, em areia, alguns coliformes e estreptococos fecais, chegaram a distâncias de até 30 metros dos poços de recarga (Baier e Wesher, 1971), (Brown et al., 1978).

$\mathrm{Na}$ Inglaterra, verificou-se que um percurso de 10 metros elimina bactérias patogênicas e os vírus, em apenas 2,5 metros. Entretanto, em áreas de infiltração de efluente secundário sobre fraturas no vale de Lu (Inglaterra), os vírus são eliminados em até 335 metros e a Escherichia coli e o Streptococo fecal em até 2 quilômetros (Baxter e Edworthy, 1979)

$\mathrm{Na}$ Polônia, em meio saturado, os coliformes penetram até 50 centímetros, desaparecem rapidamente e voltam a aparecer abaixo de 1 metro em meio totalmente anaeróbio (Blaszyk e Pawwka, 1972).

$\mathrm{Na}$ Espanha, em cascalhos grosseiros e finos com um tempo de trânsito de 1 hora, em 60 metros de distância não foram detectados bactérias fecais devido à pré-cloração efetuada (Custódio e Vilaro, 1976), (Custódio et al., 1977).

$\mathrm{Na}$ Alemanha foi observado um tempo de trânsito da água no subsolo curto, variando de 10 horas a vários dias, onde o decaimento biológico também foi conseguido através de pré e pós tratamento (Frank, 1979).

A retenção da água em superfície (tanques e lagoas) auxiliam na eliminação de bactérias; em 96 horas de retenção, o vírus da pólio tipo 3 , reduziu na ordem de 1000 vezes (Anon, 1979).

A melhor eliminação de vírus se dá em $\mathrm{pH}$ variando entre 7 e 7,5 (Drenray e 
Eliassen, 1968). Utilizando 2,5 metros de areia calcária, com $11 \%$ de lodo e argila, Lance et al. (1976) verificou que a eliminação de vírus se dá na ordem de 1000 vezes.

Na Lituânia, em charcos verificou-se que ao duplicar a espessura da camada de sedimentos, a capacidade de purificação multiplicou-se por 10 (N.U., 1977).

A maior eliminação de colis fecais corresponde ao primeiro metro de solo percolado (Gould, 1971).

$\mathrm{Na}$ Holanda, 2 meses de tempo de trânsito no subsolo eliminou totalmente vírus e bactérias (Puffelen, 1979).

O deslocamento de bactérias e vírus no subsolo é mais lento que o da água e, o dos vírus, mais lento que o das bactérias. A diferença dos vírus para as bactérias é que estes não se reproduzem e nem se proliferam no aqüífero, pois para isto necessitam de uma célula hospedeira.

\section{LEGISLAÇÃO SOBRE PERÍMETROS DE PROTEÇÃOO} possuem legislação estabelecendo perímetros de proteção em torno de captações de água subterrâneas, porém, a preocupação em preservar os recursos hídricos é crescente e, vários países já os adotam como medida preventiva para manter a qualidade destas águas. As limitações e os critérios variam de um país para outro, contudo, existe um fator comum que é representado pela delimitação de áreas de primeira, segunda e terceira ordem, com contornos superficiais crescentes a partir da captação, nos quais as atividades humanas ficam sujeitas a restrições e controle numa proporção cada vez menos rigorosa a medida que se afasta do ponto de captação.

Examinando as legislações internacionais, Pacheco (1984), verificou que alguns países europeus e também os Estados Unidos da América do Norte, possuem leis relativas à captação de águas subterrâneas, fortemente apoiadas por órgãos institucionais que garantem sua aplicação. Estas leis determinam que sejam delimitados perímetros de proteção variados em torno das captações; que sejam criados órgãos financeiros que subsidiem os recursos necessários às obras de saneamento; e, que as diretrizes a serem seguidas sejam fixadas por instituições 80 nacionais.

Destacou também que a legislação francesa é a mais adequada e precisa no que concerne à proteção da qualidade das águas subterrâneas. Em 1902, a lei já previa a instituição de perímetro de proteção contra a poluição ao redor das captações de água, enquanto que, somente a partir da década de 50 os países industrializados modificaram suas legislações para melhor combater a degradação de seus recursos hídricos, instituindo os perímetros de proteção.

Segundo Waegeningh (1985), os países europeus utilizam sistemas multidisciplinares para enfrentar o problema de proteção das águas subterrâneas, os quais, em alguns casos, são incorporados na legislação. É difícil comparar sistemas de proteção em países diferentes, devido às circunstâncias sócio-econômicas e políticas de cada país. Entretanto, pode-se mostrar, esquematicamente, como estes países definem suas áreas de proteção, conforme mostra o Quadro 1.

No Brasil, a legislação referente às águas subterrâneas é baseada no Código de Águas, criado pelo Decreto $n^{\circ} 24.643$ de 10/07/1934.

Em 08/08/1945 o Departamento Nacional de Produção Mineral (DNPM), editou o Código de Águas Minerais através do Decreto-Lei no 7.841.

Em 28/07/1997 a Portaria DNPM $n^{\circ}$ 222, aprovou o Regulamento Técnico $n^{\circ}$ 001/97 que dispõe sobre as "Especificações técnicas para o aproveitamento das águas minerais e potáveis de mesa", o qual disciplina e uniformiza os procedimentos a serem observados na fiscalização das concessões em todo o território nacional.

Em 31/07/1998 a Portaria DNPM n ${ }^{\circ}$ 231, atendendo ao que estabelece o Artigo $n^{\circ} 12$ do Decreto-Lei $n^{\circ} 7.841 / 45$, resolve que os titulares de alvará de pesquisa de água classificada como mineral ou potável de mesa, natural, devem apresentar a "área de proteção" de sua fonte, inclusa no Relatório Final dos Trabalhos de Pesquisa.

Para a definição de perímetros de proteção a portaria estabelece três diferentes zonas, segundo suas características hidráulicas:

Zona de influência - área referente ao cone de depressão (rebaixamento da superfície potenciométrica).

Zona de contribuição - área de recarga associada ao ponto de captação, 
delimitadas pelas linhas de fluxo que convergem a este ponto.

Zona de transporte - área localizada entre a área de recarga e o ponto de captação. É a zona que determina o tempo de trânsito que um contaminante leva para atingir o ponto de captação desde a área de recarga.

No Estado de São Paulo, a Lei Estadual $\mathrm{n}^{\circ} \quad 6.134$ de 02/06/1988, regulamentada pelo Decreto $n^{\circ} 32.955$ de 07/02/1991, dispõe sobre a preservação dos depósitos naturais de águas subterrâneas do Estado através de programa permanente de proteção e conservação. Este Decreto apresenta a seguinte classificação para áreas de proteção:

"Área de proteção máxima", "Área de restrição e controle" e "Área de proteção de poços e outras captações". Estabelece ainda que, nas áreas de proteção de poços e outras captações, deve ser instituído o "Perímetro imediato de proteção sanitária" (10 metros de raio a partir do ponto de captação) e o "Perímetro de alerta contra poluição" (distância equivalente ao tempo de trânsito de 50 dias, coaxial ao sentido do fluxo das águas subterrâneas).

Apesar da legislação do Estado de São Paulo estabelecer critérios para a preservação de seus recursos hídricos, não define claramente perímetros de proteção para captações de água por fontes e nascentes naturais.

\begin{tabular}{|c|c|c|c|c|}
\hline \multirow{2}{*}{\begin{tabular}{|l|}
\multicolumn{1}{|c|}{ PAÍS } \\
Ex-Alemanha \\
Ocidental
\end{tabular}} & \multicolumn{4}{|c|}{ PERÍMETROS DE PROTEÇÃO DE CAPTAÇÕES } \\
\hline & zona I & zona II & zona IIIA & zona IIIB \\
\hline & $10 \mathrm{~m}$ & 50 dias & $2 \mathrm{~km}$ & \\
\hline \multirow[t]{2}{*}{$\begin{array}{l}\text { Ex-Alemanha } \\
\text { Oriental }\end{array}$} & zona I & zona II & zona IIIA & zona IIIB \\
\hline & 5 a $10 m$ & 60 dias & 10 anos & 25 anos \\
\hline \multirow{2}{*}{ Suíça } & zona I & zona II & zona IIIA & zona IIIB \\
\hline & 10 a $20 m$ & $\begin{array}{l}10 \text { dias ou } \\
100 \mathrm{~m}\end{array}$ & $200 \mathrm{~m}$ & \\
\hline \multirow[t]{2}{*}{ Holanda } & área de captação & Zona de proteção & zona de proteção & \\
\hline & $\begin{array}{l}50 \text { a } 60 \text { dias ou } \\
30 \text { a } 150 \mathrm{~m}\end{array}$ & $\begin{array}{l}10 \text { anos ou } \\
800 \mathrm{~m}\end{array}$ & $\begin{array}{l}25 \text { anos ou } \\
1200 \mathrm{~m}\end{array}$ & \\
\hline \multirow[t]{2}{*}{ França } & $\begin{array}{c}\text { perímetro de } \\
\text { proteção imediato }\end{array}$ & $\begin{array}{l}\text { Perímetro de prot. } \\
\text { Intermediário }\end{array}$ & $\begin{array}{c}\text { perímetro de } \\
\text { proteção afastado }\end{array}$ & \\
\hline & 10 a $20 m$ & $\begin{array}{l}100 \text { dias ou } \\
200 \text { a } 500 \mathrm{~m}\end{array}$ & $1 \mathrm{a} 2 \mathrm{~km}$ & \\
\hline \multirow[t]{2}{*}{ Áustria } & $\begin{array}{c}\text { área de proteção } \\
\text { imediata }\end{array}$ & Área de proteção & $\begin{array}{c}\text { área de proteção } \\
\text { parcial }\end{array}$ & \\
\hline & & 50 dias & & \\
\hline \multirow[t]{2}{*}{ Bélgica } & $\begin{array}{c}\text { área de proteção } \\
\text { imediata }\end{array}$ & $\begin{array}{c}\text { Área de proteção } \\
\text { intermediária }\end{array}$ & $\begin{array}{c}\text { área de proteção } \\
\text { remota }\end{array}$ & \\
\hline & $24 \mathrm{~h}$ ou $100 \mathrm{~m}$ & $\begin{array}{c}50 \text { dias ou } \\
300 \text { a } 1000 \mathrm{~m}\end{array}$ & & \\
\hline \multirow[t]{2}{*}{ Finlândia } & área imediata & $\begin{array}{c}\text { zona de proteção } \\
\text { interna }\end{array}$ & $\begin{array}{c}\text { zona de proteção } \\
\text { externa }\end{array}$ & \\
\hline & & 60 dias & & \\
\hline \multirow[t]{2}{*}{ Ex-Tchecoslováquia } & $\begin{array}{l}\text { zona primária de } \\
\text { proteção sanitária }\end{array}$ & $\begin{array}{c}\text { zona secundária } \\
\text { interna de } \\
\text { proteção sanitária }\end{array}$ & $\begin{array}{c}\text { zona secundária } \\
\text { externa de } \\
\text { proteção sanitária }\end{array}$ & \\
\hline & 10 a $50 m$ & & & \\
\hline \multirow[t]{2}{*}{ Suécia } & área do poço & $\begin{array}{c}\text { área de proteção } \\
\text { interna }\end{array}$ & $\begin{array}{c}\text { área de proteção } \\
\text { externa }\end{array}$ & \\
\hline & & 60 dias ou $100 \mathrm{~m}$ & & \\
\hline \multirow[t]{2}{*}{ Hungria } & zona de proteção & $\begin{array}{c}\text { Área de proteção } \\
\text { hidrogeológica }\end{array}$ & & \\
\hline & 50 dias & 25 a 100 anos & & \\
\hline \multirow[t]{2}{*}{ Grã-Bretanha } & $\begin{array}{c}\text { área de proteção } \\
\text { imediata }\end{array}$ & & & \\
\hline & 10 a $50 \mathrm{~m}$ & & & \\
\hline
\end{tabular}




\begin{tabular}{|c|c|c|c|c|}
\hline PAÍS & \multicolumn{4}{|c|}{ PERÍMETROS DE PROTEÇÃO DE CAPTAÇÕES } \\
\hline $\begin{array}{l}\text { Estados Unidos da } \\
\text { América do Norte }\end{array}$ & $\begin{array}{l}\text { zona de influência } \\
\text { ou remediação }\end{array}$ & $\begin{array}{c}\text { zona de } \\
\text { transporte ou } \\
\text { atenuação }\end{array}$ & $\begin{array}{c}\text { zona de } \\
\text { contribuição ou } \\
\text { gerenciamento }\end{array}$ & \\
\hline Brasil & zona de influência & $\begin{array}{l}\text { Zona de } \\
\text { transporte }\end{array}$ & $\begin{array}{c}\text { zona de } \\
\text { contribuição }\end{array}$ & \\
\hline $\begin{array}{l}\text { Brasil Estado de } \\
\text { São Paulo }\end{array}$ & \multicolumn{2}{|c|}{$\begin{array}{c}\text { área de proteção de poços e outras } \\
\text { captações }\end{array}$} & $\begin{array}{c}\text { área de restrição } \\
\text { e controle }\end{array}$ & $\begin{array}{c}\text { área de proteção } \\
\text { máxima }\end{array}$ \\
\hline & $\begin{array}{c}\text { perímetro } \\
\text { imediato de prot. } \\
\text { sanitária }\end{array}$ & $\begin{array}{l}\text { Perímetro de } \\
\text { alerta contra } \\
\text { poluição }\end{array}$ & & \\
\hline & $10 \mathrm{~m}$ & 50 dias & & \\
\hline
\end{tabular}

Resumo sobre perímetros de proteção de captações em diferentes países (Waegeningh, 1985), (USEPA,1987), (DNPM, Portaria n²31/1998) e (Lei Estadual nº 6137/88-SP).

\section{JUSTIFICATIVA PARA A METODOLOGIA PROPOSTA}

A metodologia mais utilizada para delimitar perímetros de proteção de poços e fontes naturais, segundo estudos realizados, é a aplicação de modelagem numérica tridimensional.

A representação artificial do sistema aqüífero através de modelos matemáticos necessita de estudos detalhados das condições hidrogeológicas do fluxo subterrâneo, de qualidade e quantidade de dados suficientes para uma representação confiável e próxima da realidade.

No caso de poços, a aplicação dessa metodologia é viável, tendo em vista que o bombeamento de um poço provoca o rebaixamento da superfície piezométrica. O cone de depressão formado, define as condições do fluxo do sistema aqüífero, cuja área, segundo a Portaria DNPM n ${ }^{\circ} 231$ de $31 / 07 / 1998$, determina a primeira zona de proteção de uma captação, a Zona de Influência.

Em fontes ou nascentes naturais, o cone de rebaixamento não ocorre. Estas funcionam como um dreno, logo, a Zona de Influência de uma fonte natural não pode ser definida como sendo a área referente ao rebaixamento piezométrico.

A questão aqui levantada é que a metodologia usualmente aplicada para delimitar perímetros de proteção onde ocorrem fontes ou nascentes naturais, pode não representar seguramente o sistema físico real do aqüífero.

Desse modo, a metodologia proposta, valendo-se dos princípios básicos da Física, pode determinar perímetros de proteção seguros para fontes naturais, utilizando a condutividade hidráulica e o tempo de decaimento bacteriológico e virológico no subsolo.

\section{METODOLOGIA PARA DEFINIÇÃO DO PERÍMETRO DE PROTEÇÃO DE FONTES NATURAIS}

Para sua aplicação é necessário a realização de três etapas seqüenciais: procedimentos de campo, procedimentos de laboratório e procedimentos de escritório (cálculos e análise dos resultados).

\section{Procedimentos de campo}

Nesta primeira etapa deve-se fazer o mapeamento hidrogeológico de detalhe da área onde se localiza a fonte. Para isto, é fundamental fazer o reconhecimento geológico detalhado, caracterizando estruturas e litologias condicionantes do sistema hidrogeológico local.

Quando não existirem pontos d'água dentro da microbacia hidrográfica que possam influenciar na caracterização de sua rede de fluxo, recomenda-se perfurar poços para constatar o nível do aqüífero freático e, posteriormente, elaborar um mapa potenciométrico, indicando as linhas de fluxo das águas subterrâneas.

De posse do mapa potenciométrico e com a caracterização das linhas de fluxo, locar pontos de amostragem de solo, de modo representativo para a litologia presente e, que estejam dentro do conjunto de linhas de fluxo que tenham sua convergência para o ponto de surgência da fonte.

Assim, as amostras coletadas devem 
refletir, com a maior representatividade possível, as características granulométricas do solo, proporcionando a obtenção das condições hidrodinâmicas do meio, que influenciam a condutividade hidráulica do solo local.

As amostras devem ser coletadas em função do manto de alteração e, se possível, que representem todo seu perfil, preferencialmente, na zona não saturada, pois este é o elemento filtrante e condicionante da condutividade hidráulica das águas de recarga ou, de possíveis fontes de poluição/contaminação.

Estas amostras, quando possível, devem ser homogeneizadas metro a metro, para o reconhecimento de possíveis variações de condutividade hidráulica ao longo do perfil amostrado.

Havendo possibilidade local, recomenda-se a realização de ensaios de infiltração nos locais amostrados, cujos resultados podem ser comparados com os resultados laboratoriais.

\section{Procedimentos de laboratório}

A granulometria é a propriedade física fundamental para a determinação da condutividade hidráulica; portanto, as amostras coletadas devem ser analisadas granulometricamente, segundo os métodos de pipetagem, elutriação e peneiramento.

Estes métodos são aplicados freqüentemente, em amostras granulometricamente heterogêneas, com partículas argilosas, até areias grosseiras, muito grosseiras ou ainda, grânulos e seixos, fazendo-se necessário combinar tais métodos, de maneira que os grãos mais grossos sejam peneirados e os mais finos pipetados (Suguio, 1973).

Os resultados obtidos tanto na pipetagem como no peneiramento, são transcritos para um programa de computador que realiza os cálculos e fornece os resultados finais das análises granulométricas.

\section{Procedimentos de escritório}

Os dados de granulometria dos solos são plotados no Diagrama Triangular de Shepard. Este, fornecerá a classificação textural das amostras.

De acordo com Fetter (1988), existe uma relação direta entre a classificação textural, a permeabilidade intrínseca e a condutividade hidráulica, conforme tabela à seguir. Estes valores serão utilizados no cálculo dos perímetros de proteção das fontes:

\begin{tabular}{l|l|l}
\hline \multicolumn{1}{c|}{ Material } & \multicolumn{1}{c|}{$\begin{array}{c}\text { Permeabilidade Intrínseca } \\
(\mathbf{c m} / \mathbf{s})\end{array}$} & \multicolumn{1}{c}{$\begin{array}{c}\text { Condutividade Hidráulica } \\
\text { (cm/s) }\end{array}$} \\
\hline Argila Silte; Silte arenoso & $10^{-14}-10^{-11} 10^{-11}-10^{-9} 10^{-11}-$ & $10^{-9}-10^{-6} 10^{-6}-10^{-4} 10^{-6}-10^{-4}$ \\
Areia argilosa Areia siltosa; & $10^{-9} 10^{-10}-10^{-8} 10^{-8}-10^{-6} 10^{-7}$ & $10^{-5}-10^{-3} 10^{-3}-10^{-1} 10^{-2}-10^{\circ}$ \\
$\begin{array}{l}\text { Areia fina Areia bem } \\
\text { distribuída Cascalho bem } \\
\text { distribuído }\end{array}$ & $-10^{-5}$ & \\
\hline
\end{tabular}

Faixa de valores de permeabilidade intrínseca e condutividade hidráulica para vários materiais não consolidados (Fetter, 1988).

Onde for possível, deve-se realizar ensaios de permeabilidade para determinar a condutividade hidráulica $(\mathrm{K})$ do solo, a qual auxiliará no cálculo da velocidade média da água subterrânea local e servirá como parâmetro comparativo dos resultados finais da metodologia proposta. O valor de $\mathrm{K}$ é determinado através da seguinte equação:

onde:

$$
K=d h / d t .(r / R)^{2}
$$

dh = variação do nível d'água no furo durante o ensaio [L]

$\mathrm{dt}=$ intervalo de tempo de duração do ensaio [T]

$r=$ raio do furo $[\mathrm{L}]$
$\mathrm{R}=$ raio da parábola com vértice no centro do furo, na altura do nível d'água inicial $(\mathrm{t}=0)$, da pela equação $\mathrm{R}^{2}+\mathrm{R}-\mathrm{h}=0$ (em metros) [L]

$\mathrm{K}=$ condutividade hidráulica $[\mathrm{L}] \times[\mathrm{T}]^{-1}$

A partir da condutividade hidráulica calculada em cada vertente topográfica, calcula-se a velocidade média da água subterrânea através do gradiente hidráulico entre dois poços alinhados em posições extremas em cada vertente (montante/jusante).

O gradiente hidráulico é calculado pela seguinte equação (Fetter, 1994): 
onde:

$$
i=d H / d x
$$

$\mathrm{dH}=$ diferença entre as cargas hidráulicas de dois poços [L]

$\mathrm{dx}=$ distância horizontal entre os dois poços [L]

i = gradiente hidráulico (grandeza adimensional)

A velocidade média da água subterrânea é calculada pela seguinte equação:

onde:

$$
v=K . i / n_{e}
$$

$\mathrm{K}=$ condutividade hidráulica $[\mathrm{L}] \times[\mathrm{T}]^{-1}$

i = gradiente hidráulico (grandeza adimensional)

$\mathrm{n}_{\mathrm{e}}=$ porosidade efetiva (grandeza adimensional)

$\mathrm{v}=$ velocidade média $[\mathrm{L}] \times[\mathrm{T}]^{-1}$

Finalmente, os perímetros de proteção das fontes são calculados aplicando-se a equação da velocidade, função espaço x tempo:

onde:

$$
\mathbf{v}=\mathbf{s} / \mathbf{t} \text { ou } \mathbf{s}=\mathbf{v} . \mathbf{t}
$$

$\mathbf{v}=$ velocidade dada pela condutividade hidráulica (K) (metros/segundo)

$\mathbf{t}=$ tempo de trânsito da água no subsolo (segundos)

$\mathbf{s}=$ distância de proteção das fontes (metros)

Os resultados destes cálculos permitem a delimitação dos perímetros de proteção das fontes, conforme determina a Portaria DNPM n 231/98.

Por tratar-se de fontes ou nascentes naturais, optou-se pela modificação da denominação de cada zona de proteção:

Zona de Influência para ZONA IMEDIATA - até 10 metros ao redor da captação, cercada e controlada, na qual se exclui qualquer atividade, armazenamento, manipulação ou aplicação que seja perigosa e que possa comprometer a qualidade da água. Deve-se salientar que esta distância é obrigatória e não depende da geologia local.

\section{Zona de Transporte para ZONA PRÓXIMA} preferencialmente para proteção bacteriológica. O limite externo é fixado em termos de tempo de trânsito da água de até 100 dias, desde a superfície do terreno até a fonte captada. São toleradas apenas certas 84 atividades não contaminantes, certos armazenamentos em condições bem controladas e acesso restrito para pessoas e veículos.

Zona de Contribuição para ZONA AFASTADA - abrange os limites naturais da bacia hidrográfica (divisores de água) ou uma distância suficiente para a obtenção de tempos de trânsito acima de 100 dias. Sua extensão e forma é muito variável, desde várias centenas de metros até mais de 1 quilômetro. Existem certas restrições de uso da terra com relação à ocupação industrial e urbana, determinadas práticas agrícolas e na forma de planejar ou manter vias de comunicação.

\section{APLICAÇÃO DA METODOLOGIA}

Três áreas foram selecionadas para a aplicação da metodologia proposta levando-se em consideração seus aspectos geológicos distintos.

Duas áreas estão localizadas no Estado de São Paulo, nos municípios de Piedade (Área I) e Cotia (Área II), as quais estão inseridas em relevos cristalinos. A terceira área está localizada no Estado do Mato Grosso do Sul, no município de Itaquiraí (Área III) e está inserida em relevo sedimentar.

Na Área I, a geologia predominante é o granito, onde afloram matacões e o solo é pouco espesso; na Área II, predominam gnaisses migmatizados, com afloramento de rocha e solo pouco espesso; e na Área III, temos rochas sedimentares areníticas com solo espesso.

As tabelas e diagramas a seguir, mostram os resultados granulométricos que definem os tipos de solos estudados. Com base nestes resultados, podemos identificar o intervalo da condutividade hidráulica a ser utilizado nos cálculos dos perímetros de proteção das fontes.

\begin{tabular}{l|l|l|l|l|l}
\hline \multicolumn{2}{c|}{ Amostra } & \multicolumn{3}{c|}{ Fração } & \multicolumn{1}{c}{$\begin{array}{l}\text { Classificação } \\
\text { de Shepard }\end{array}$} \\
\hline Ponto & $\begin{array}{l}\text { Prof. } \\
\text { (m) }\end{array}$ & Areia & Silte & Argila & \\
\hline GS1 & 1,50 & 59,77 & 13,33 & 26,89 & areia argilosa \\
\hline GS2 & 1,20 & 61,00 & 24,11 & 14,89 & areia síltica \\
\hline GS3 & 1,30 & 49,43 & 13,14 & 37,41 & areia argilosa \\
\hline GS4 & 0,50 & 57,17 & 16,79 & 26,02 & areia argilosa \\
\hline GS5 & 0,75 & 46,89 & 24,15 & 28,98 & $\begin{array}{l}\text { areia síltica } \\
\text { argilosa }\end{array}$ \\
\hline GS6 & 1,10 & 50,64 & 16,34 & 33,03 & areia argilosa \\
\hline
\end{tabular}




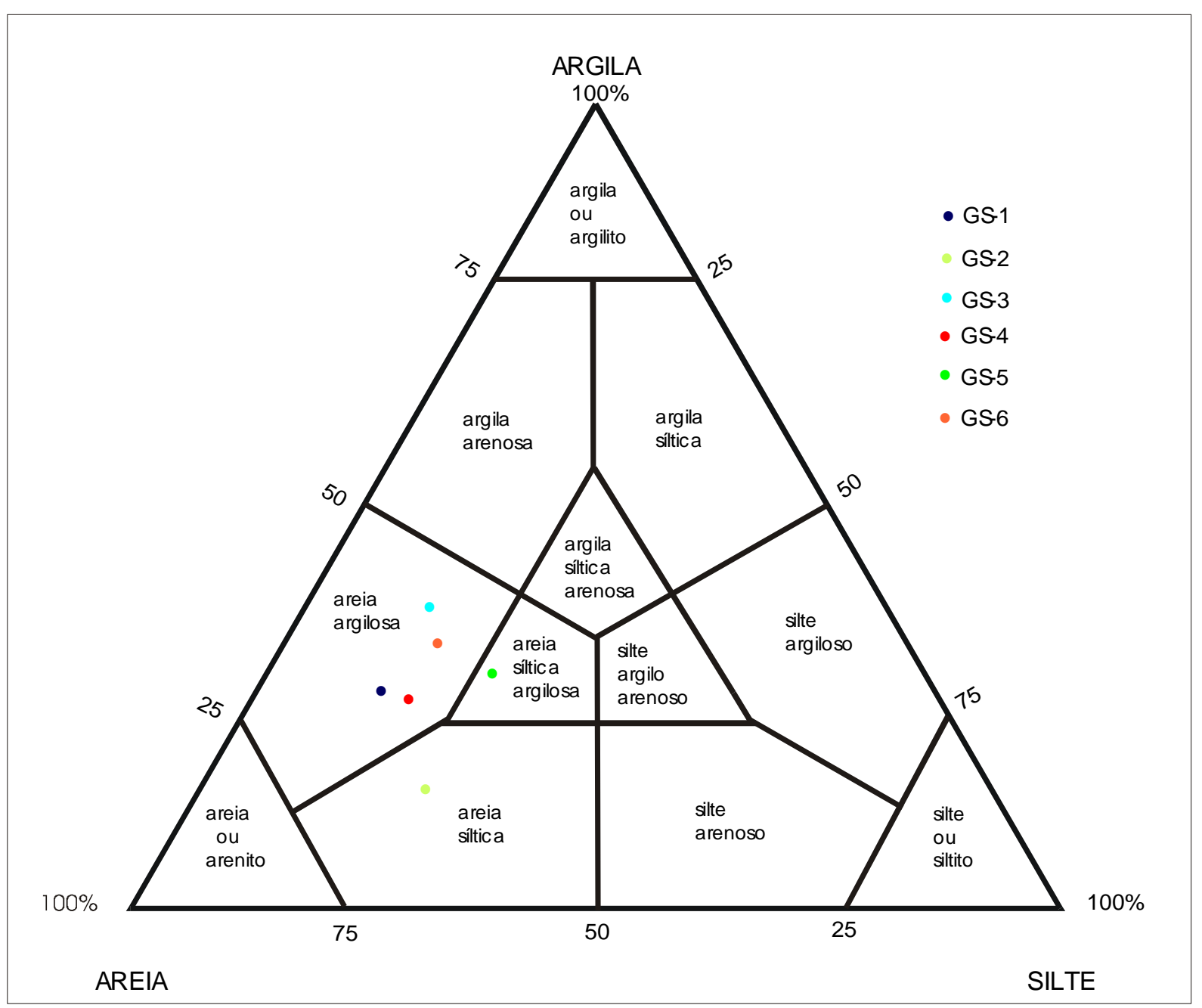

Diagrama Triangular de Shepard classificando as amostras de solo da Área I

\begin{tabular}{c|c|c|c|c|c}
\hline \multicolumn{2}{c|}{ Amostra } & \multicolumn{3}{c|}{ Fração Granulométrica (\%) } & $\begin{array}{c}\text { Classificação de } \\
\text { Shepard }\end{array}$ \\
\hline Ponto & Prof. (m) & Areia & Silte & Argila & \\
\hline A-1 & 0,80 & 56,34 & 27,95 & 15,68 & areia síltica \\
\hline A-2 & 0,80 & 56,53 & 22,01 & 21,49 & areia síltica \\
\hline
\end{tabular}

Distribuição das frações granulométricas nos pontos analisados da Área II e respectiva classificação textural, segundo Shepard. 


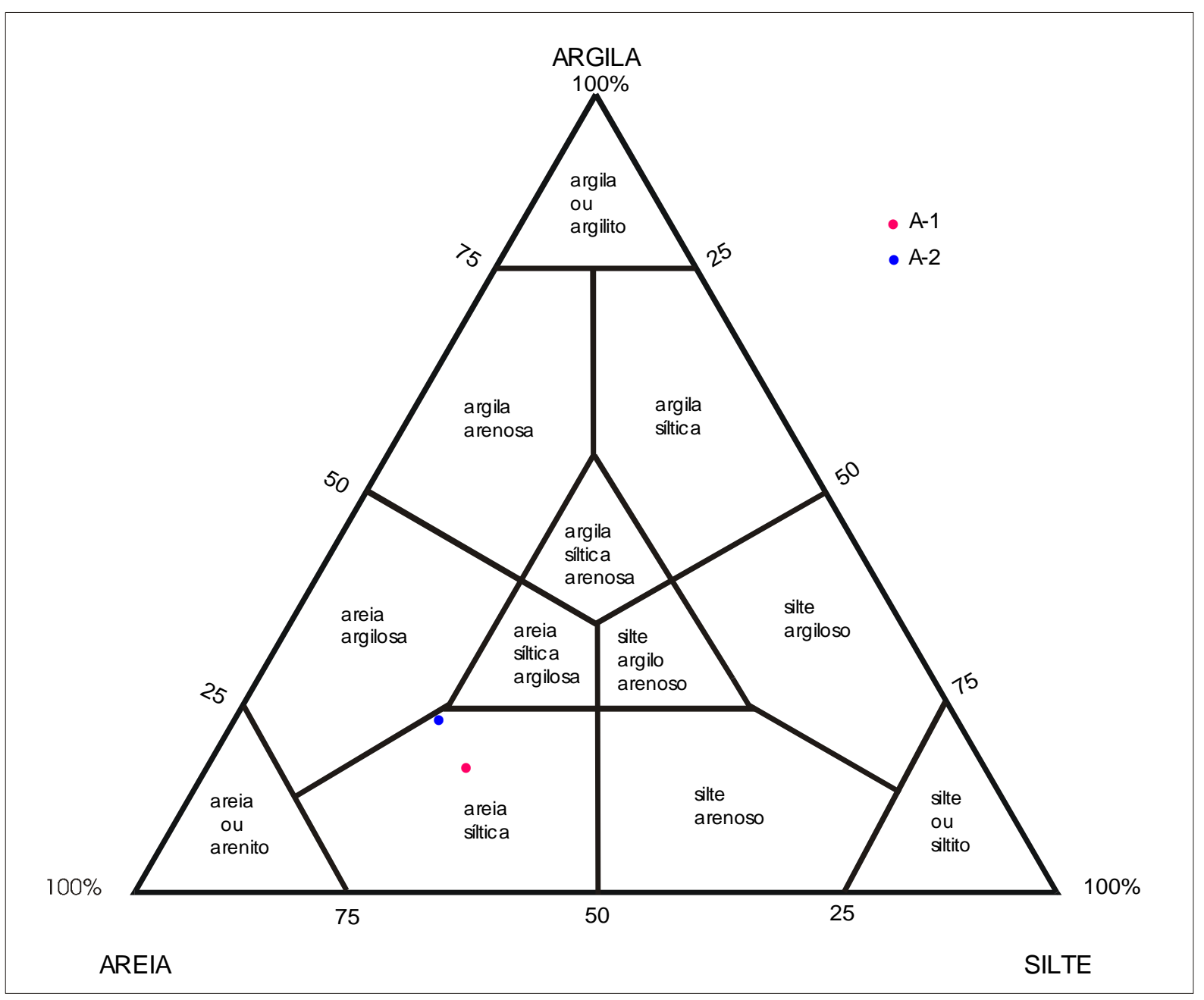

Diagrama Triangular de Shepard classificando as amostras de solo da Área II

\begin{tabular}{c|c|c|c|c|c|c}
\hline \multicolumn{3}{c|}{ Amostra } & \multicolumn{3}{c}{ Fração Granulométrica (\%) } & $\begin{array}{c}\text { Classificação de } \\
\text { Shepard }\end{array}$ \\
\hline \multicolumn{2}{c|}{ Ponto } & Prof. (m) & Areia & Silte & Argila & areia ou arenito \\
\hline F1 & 1 & 1,10 & 80,67 & 2,64 & 16,69 & areia ou arenito \\
\hline & 2 & 2,20 & 75,72 & 3,51 & 17,96 & areia argilosa \\
\hline F2 & 1 & 1,10 & 73,25 & 4,86 & 21,88 & areia argilosa \\
\hline & 2 & 2,20 & 71,38 & 4,45 & 24,17 & areia ou arenito \\
\hline F3 & 1 & 1,10 & 84,23 & 3,97 & 11,80 & areia ou arenito \\
\hline & 2 & 2,20 & 81,59 & 3,11 & 15,30 & areia argilosa \\
\hline F4 & 1 & 1,10 & 70,57 & 5,34 & 24,08 & areia argilosa \\
\hline F5 & 2 & 2,20 & 72,77 & 5,13 & 22,09 & areia argilosa \\
\hline & 1 & 1,10 & 74,09 & 5,71 & 20,19 & areia argilosa \\
\hline F6 & 2 & 2,20 & 72,21 & 4,58 & 23,22 & areia argilosa \\
\hline & 2 & 1,10 & 64,30 & 4,86 & 30,85 & areia argilosa \\
\hline
\end{tabular}

Distribuição das frações granulométricas nos pontos analisados da Área III e respectiva classificação textural, segundo Shepard. 


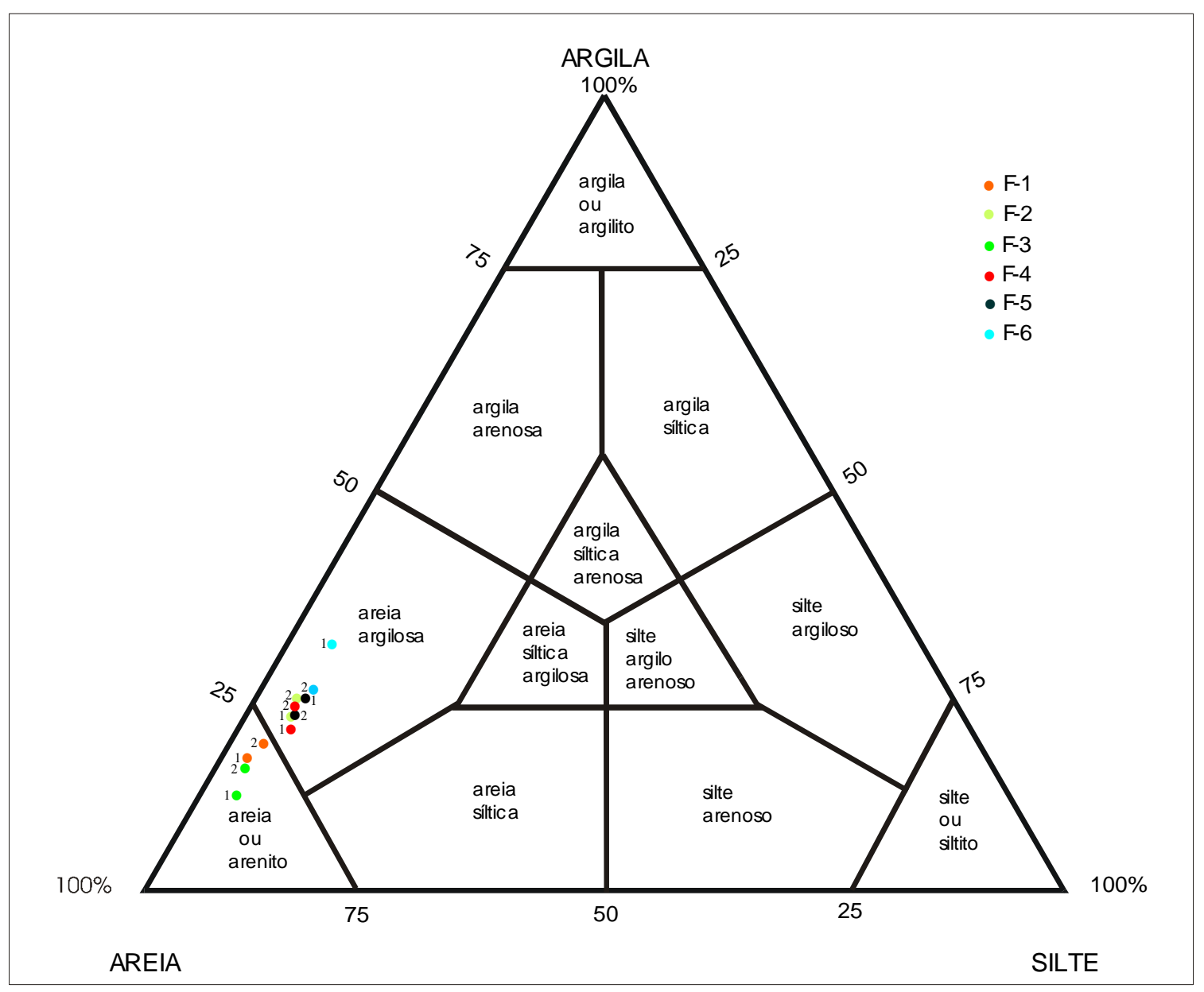

Diagrama Triangular de Shepard classificando as amostras de solo da Área III.

Os quadros a seguir, mostram os resultados das classificações granulométricas dos solos estudados, conseguidos através dos diagramas e, de acordo com Fetter (1988), apresentam a correlacão existente entre a granulometria do solo à permeabilidade intrínseca e à condutividade hidráulica.

\begin{tabular}{|l|l|l|}
\hline $\begin{array}{l}\text { Dados } \\
\text { obtidos }\end{array}$ & $\begin{array}{l}\text { Permeabilida } \\
\text { de intrínseca } \\
\left(\mathbf{c m}^{2}\right)\end{array}$ & $\begin{array}{l}\text { Condutivida } \\
\text { de hidráulica } \\
(\mathbf{c m} / \mathbf{s})\end{array}$ \\
\hline $\begin{array}{l}\text { areia } \\
\text { argilosa }\end{array}$ & $10^{-11}-10^{-9}$ & $\mathbf{1 0}^{-6}-\mathbf{1 0}^{-4}$ \\
\hline $\begin{array}{l}\text { areia síltica } \\
\text { argilosa }\end{array}$ & $10^{-11}-10^{-9}$ & $\mathbf{1 0}^{-6}-\mathbf{1 0}^{-4}$ \\
\hline areia síltica & $10^{-10}-10^{-8}$ & $\mathbf{1 0}^{-5}-10^{-3}$ \\
\hline
\end{tabular}

Área I

\begin{tabular}{|l|l|l|}
\hline $\begin{array}{l}\text { Dados } \\
\text { obtidos }\end{array}$ & $\begin{array}{l}\text { Permeabilida } \\
\text { de intrínseca } \\
\left(\mathbf{c m}^{2}\right)\end{array}$ & $\begin{array}{l}\text { Condutivida } \\
\text { de hidráulica } \\
(\mathbf{c m} / \mathbf{s})\end{array}$ \\
\hline areia síltica & $10^{-10}-10^{-8}$ & $10^{-5}-10^{-3}$ \\
\hline
\end{tabular}

\begin{tabular}{|l|l|l|}
\hline $\begin{array}{l}\text { Dados } \\
\text { obtidos }\end{array}$ & $\begin{array}{l}\text { Permeabilid } \\
\text { ade } \\
\text { intrínseca } \\
\left(\mathbf{c m}^{2}\right)\end{array}$ & $\begin{array}{l}\text { Condutivida } \\
\text { de } \\
\text { hidráulica } \\
\text { (cm/s) }\end{array}$ \\
\hline $\begin{array}{l}\text { Areia } \\
\text { argilosa }\end{array}$ & $10^{-11}-10^{-9}$ & $\mathbf{1 0}^{-6}-\mathbf{1 0}^{-4}$ \\
\hline areia fina & $10^{-10}-10^{-8}$ & $\mathbf{1 0}^{-5}-\mathbf{1 0}^{-3}$ \\
\hline
\end{tabular}

Área III

Nos três casos estudados, a faixa de condutividade hidráulica obtida varia de $10^{-6}$ a $10^{-3}(\mathrm{~cm} / \mathrm{s})$. Desse modo, para resultados mais seguros, adotou-se o maior valor de condutividade hidráulica e o tempo de trânsito da água no subsolo de 100 dias, considerado suficiente para eliminação de vírus e bactérias patogênicas.

Portanto, o resultado do cálculo para a delimitação da área de proteção, referente à Zona Próxima (responsável pela segurança microbiológica) foi de 86,40 metros de raio a partir da captação. 
As demais Zonas (Imediata e Afastada), como já foi visto, independem de cálculos, pois a zona Imediata está fixada em 10 metros de raio a partir da captação e a Zona Afastada abrange os limites naturais da bacia hidrográfica local ou uma distância correspondente à obtenção de tempos de trânsito acima de 100 dias.

\section{CONCLUSÕES}

A partir da conceituação dos termos poluição e contaminação, fontes pontuais e difusas de suas ocorrências, são discutidos, com base em literatura científica, os aspectos comportamentais da poluição/contaminação no meio poroso insaturado e nos aqüíferos, principalmente com relação ao comportamento das bactérias patogênicas, causadoras universais de grandes epidemias por doenças de veiculação hídrica.

Em estudos realizados com recarga artificial de aqüíferos, para a verificação do fator de decaimento de vírus e bactérias patogênicas, fica ressaltado que a distância de decaimento é intrínseca ao meio geológico pesquisado, enquanto que o tempo de trânsito do decaimento independe do meio geológico, sendo função do tempo de vida nesse meio subterrâneo. Desse modo, fixar distâncias mínimas, não se aplica aos diferentes contextos geológicos, logo, não pode ser utilizado como padrão. Assim, a utilização do tempo de decaimento é o que melhor representa a realidade e pode ser aplicada de forma mais correta.

São feitas considerações sobre a legislação internacional e nacional referente ao estabelecimento de perímetros de proteção nos entornos das captações de água subterrânea, tendo em vista a crescente preocupação mundial na preservação da qualidade dos recursos hídricos.

No quadro resumo apresentado sobre perímetros de proteção de captações em diferentes países, inclusive o Brasil e o Estado de São Paulo, observa-se que, a maioria dos países apontados adotam três áreas (ou zonas) de proteção, variando a distância ao ponto de captação, ou o tempo de trânsito da água desde o ponto de recarga até 0 ponto de captação. Logicamente, o caráter empírico de distância reflete as características geológicas do meio poroso, onde foram executadas as pesquisas orientadas das legislações. 88
As legislações baseadas em tempo de trânsito são mais realistas e podem ser aplicadas em qualquer contexto geológico, pois levam em consideração o tempo de decaimento que o contaminante, no caso, bactérias e vírus, possui até sua completa eliminação no meio poroso considerado.

A metodologia mais utilizada atualmente para definição e delimitação de perímetros de proteção em nosso país é a aplicação de modelagem numérica tridimensional, para poços tubulares profundos.

A representação hidrogeológica de uma área através de modelos matemáticos, chega bem próximo da realidade, quando os dados utilizados são suficientemente representativos quanto a sua qualidade e quantidade. Porém, quando aplicados para fontes ou nascentes naturais podem não representar, seguramente, o sistema físico real do aqüífero, dado às necessidades de calibração do modelo adotado.

A aplicação de uma metodologia específica para delimitar perímetros de proteção em fontes naturais, utiliza como conceitos básicos a condutividade hidráulica e o tempo de decaimento microbiológico no meio poroso. Nela são descritos os procediemtnos de campo, laboratório e escritório necessários para atingir o objetivo que é a definição dos perímetros de proteção. Enfatiza-se a necessidade de um reconhecimento geológico nos entornos do ponto de captação, com caracterização litológica, estrutural e potenciométrica, com finalidade de determinação do sentido das linhas de fluxo que atuam no escoamento subterrâneo e qual sua influência real nas águas subterrâneas captadas.

$\mathrm{Na}$ ausência de pontos d'água que possam justificar uma malha representativa para a construção de um mapa potenciométrico e assim, obter-se o sentido das linhas de fluxo, toda a microbacia situada a montante do ponto de captação dever ser considerada como contribuinte ou zona de recarga do sistema aqüífero, pois toda fonte natural ou surgência, mesmo situada em descontinuidade de rochas cristalinas, possue uma cobertura de manto de alteração ou solo que sofre recarga natural e transfere suas águas aos pontos de surgência, somando-se às águas de outra procedência.

No intuito de caracterização hidrodinâmica da área de possível recarga 
nos entornos do ponto de captação, a metodologia prevê a tomada de amostras do solo, que representem as distintas litologias nesta área. Estas amostras, ao serem retiradas em pontos escavados a trado, deverão representar o perfil do solo na zona não saturada, que é o elemento condicionante da entrada de água superficial e que dá a recarga efetiva ao sistema aqüífero considerado.

Estas amostras são analisadas quanto a sua textura granulométrica, classificadas e, posteriormente, relacionadas com a permeabilidade intrínseca e condutividade hidráulica, de acordo com Fetter (1988). A condutividade hidráulica, assim obtida para vários materiais não consolidados, nos proporciona um intervalo máximo e mínimo de velocidade de escoamento no meio analisado, o que nos indicará com segurança as condições hidrodinâmicas dos entornos do ponto de captação.

Levando em consideração o valor máximo da condutividade hidráulica do meio como fator de segurança e considerando em 100 dias o tempo ideal para o total decaimento bacteriológico, calculam-se as distâncias mínimas para um efetivo perímetro de proteção relacionado a este tipo de contaminante.

São então propostas três zonas de proteção denominadas:

Zona Imediata - área cercada e controlada, na qual se exclui qualquer atividade que possa comprometer a qualidade da água captada, com aproximadamente 10 metros ao redor do ponto de captação, independentemente da geologia local.

Zona Próxima - área fixada em termos de condutividade hidráulica (tempo de trânsito da água em até 100 dias) da cobertura de solo da bacia versante, na qual são admitidas atividades potencialmente não contaminantes, com acesso restrito à pessoas e meios de transporte.

Zona Afastada - área que abrange os limites naturais da bacia hidrográfica versante (área de recarga local) com tempo de trânsito de escoamento subterrâneo maior que 100 dias, na qual faz-se restrições com relação ao uso da terra, ao potencial contaminante urbano e industrial e determinadas práticas agrícolas.

Esta metodologia foi aplicada em três casos reais, onde existem pontos de captação de fontes naturais de águas minerais. Nas três áreas foram delimitados perímetros de proteção, condizentes com a geologia local, de acordo com a metodologia proposta, conforme exigência do Departamento Nacional de Produção Mineral - DNPM (Portaria 231/98).

\section{REFERÊNCIAS BIBLIOGRÁFICAS}

ANON. (1979). Biological contamination. Water Well Journal, maio 1979.

BAIER, D. C.; WESHER, G. M. (1971). Reclaimed waste water for ground-water recharge. Water Resourses Bulletin, v. 7, n. 5, p. 991-1001.

BAXTER, K. M.; EDWORTHY, K. J. (1979). Impact of sewage effluent recharge on groundwater in the chalk for an area in Soulth-East England. Symp. on Artificial Groundwater Recharge. Dortmund. V. III, paper v.10. DVWK. Bull. 13. Verlag Paul Parey. Hamburg-Berlin, p 169 201.

BEREND, J. E. (1970). Clogging processes and optimization of basin recharge. Artificial Groundwater Recharge Conference. Reading. The Water Research Assoc. England. Paper 5, p. 111-132.

BLASZYK, T.; PAWWKA, A. (1972). Recherches sur l'amelioration des eaux souterraines en Pologne. IWSA, Int. Water Supply Assoc. New York Congress. Subject Special 11, p. 25-27.

BROWN, R. F.; SIGNOR, D. C.; WOOD, W. W. (1978). Artificial ground-water recharge as a water-management technique on the Southern High Plains of Texas and New Mexico. Texas Department of Water Resources. Report 220, 32p. Austin, Texas.

CUSTODIO, E., et al. (1977). Combined use of surface and groundwater in Barcelona, Metropolitan Area (Spain). Int. Ass. Hydrogeologists. Birmingham. V. XIII, 1, p. C14-27.

CUSTODIO, E.; VILARÓ, F. (1976). Recarga artificial de acuíferos subterráneos. Hidrologia Subterránea, v. II, sec. 19 (E. Custodio y M. R. Llamas). Ediciones Omega, Barcelona, p.19632026.

DNPM - Departamento Nacional de Produção Mineral. Portaria $n^{\circ} 231$ de 31 
de julho de 1998. Diário Oficial da União de 07/08/98.

DRENRAY, W. A.; ELIASSEN, R. (1968). Virus movement in ground-water. J. Water Pollution Control Fed., v. 40, p. R257-271.

EDWORTHY, K. J.; DOWNING, R. A. (1979). Artificial recharge and its relevance in Britain. The Institution of Water Engineers and Scientists, v. 33, March, London, p. 151-172.

FETTER, C. W. (1988) Aplied Hydrogeology. In: CABRAL, J. Hidrogeologia - Conceitos e Aplicações. Fortaleza, CPRM-LABHID-UFPE. c. 3, p. 35-51.

FETTER, C. W. (1994). Applied Hidrogeology. Prentice Hall, $3^{\text {rd }}$ Ed., $691 \mathrm{p}$.

FRANK, W. H. (1979). Réalimentation artificielle dans la Republique Féderale d'Allemagne. IWSA. Int. Water Supply Assoc. New York Congress. Subject Special 11, p. L1-L2.

GOULD, B. W. (1971). Wastewater reclamation using ground-water recharge: Part 1. Effluent and Water Treatment Journal, Feb., p. 88-95.

JIMENA, E. C. (1986) Recarga Artificial de Acuiferos - Avances y realizaciones. Boletin de Informaciones y Estudos, Ministério de Obras Públicas y Urbanismo, Barcelona - Espanha, p. 94$95\left(n^{\circ} 45\right)$.

KADDU-MULINDWA, D.; FILIP, Z.; MILDE, G. (1983). Survival of some pathogenic and potential pathogenic bacteria in groundwater. Ground Water in Water Resources Planning. Int. Symp. Koblenz. UNESCO-IAH-IAHS, v. II, p. 1137-1145.

LANCE, J. C.; GERBA, C. P.; MELNICK, J. (1976). Virus movement in soil columns flooded with secondary sewage effluent. Applied and Environmental Microbiology. V. 32 (4), p. 520-526.

LOEFFLER, H., et al. (1973). Erhoehung der Grundfondseffektivitaet durch Grundwasseranreicherung. Weitere ergebnisse zu Einsatz Technologie und Bemessung. Wasserwirtschafts Wassertechnik, v. 23, p. 200-204/267-
272.

MENTE, A.; CRUZ, W. B. (1998). Área de Proteção das fontes de água mineral da região de Lindóia, Águas de Lindóia e Serra Negra - São Paulo. Brasília, DNPM. v.1.

N. U. (1977). Almacenamiento y recarga artificial de aguas subterráneas. Naciones Unidas, Recursos Naturales. Serie del Agua, n. 2. ST/ESA/13, 306p.

PACHECO, A. C. (1984) Análise das características técnicas e da legislação para uso e proteção das águas subterrâneas em meio urbano Município de São Paulo. São Paulo, 174p. Tese (Doutorado) - Instituto de Geociências, Universidade de São Paulo.

PUFFELEN, J. van (1979). Artificial groundwater recharge in the Netherlands. Int. Symp. on Artificial Groundwater Recharge. Dortmund. V. I, paper 1.3. DVWK. Bull. 11. Verlag Paul Parey. Hamburg-Berlin, p. 63-96.

ROMERO, J. C. (1970). The movement of bacteria and viruses through porous media. Ground Water, v. 8, n. 2, p. 3748.

SHELEF, G. (1979). Artificial groundwater recharge of treated effluents as part of Israels national wastewater reclamation scheme. Int. Symp. on Artificial Groundwater Recharge. Dortmund, paper I.11, p. 229-234.

SUGUIO, K. (1973) Introdução à Sedimentologia. São Paulo, Edgard Blücher. Ed. da Universidade de São Paulo. 317p.

USEPA - United State Environmental Protection Agency. (1987) Guidelines for delineation of wellhead protection areas. Washington, D.C. 185p.

WAEGENINGH, H. G. van (1985) Overview of the protection of groundwater quality. In: MATTHESS, G.; FOSTER, S. S. D.; SKINNER, A. C. Theoretical Background, Hidrogeology and Pratice of Groundwater Protection Zones. Hannover: Heise. UNESCO, International Association of Hydrogeologists, v. 6, p. 159-166.

YARUZ CARAPCIOGLU, M.; HARIDAS, A. 
Rev. Águas Subterrâneas nํ 17/ Maio 2003.

(1984). Transport and fate of microorganisms in porous media a theoretical investigation. Journal of Hydrology, 72, p. 149-167. 